\section{The Effect of the National Wildlife Federation's Schoolyard Habitat Program on Fourth Grade Students' Standardized Test Scores}

\author{
P.E. Danforth ${ }^{1}$, T.M. Waliczek ${ }^{2,5}$, S.M. Macey ${ }^{3}$, and J.M. Zajicek ${ }^{4}$
}

ADDITIONAL INDEX WORDs. academic achievement, elementary students, integrated curriculum

Summary. The purpose of this study was to determine if participation in the National Wildlife Federation's Schoolyard Habitat Program (SYHP) had an effect on the standardized test scores of fourth grade primary school students in Houston, Texas. To conduct the study, three pairs of Houston elementary schools were matched by student demographics of ethnicity and economics. The treatment group included a total of 306 fourth grade students whose teachers were using the SYHP. The control group consisted of a total of 108 fourth grade students whose teachers used a more traditional curriculum. To measure academic achievement, changes in standardized test scores (Texas Assessment of Knowledge and Skills) were compared between students' third grade data and their fourth grade data. Results showed that those students participating in the SYHP had significantly increased math scores when compared with peers in schools that were taught using a more traditional curriculum. However, overall, few differences were found in comparisons of reading scores of those students taught with SYHP and those taught using a more traditional curriculum.

$\mathrm{E}$ ducation in primary and secondary schools in the late 19th and 20th century began to shed some of the more traditional teachings in favor of vocational course work that reflected the job market's needs (Ravitch, 2000). Out of this progressive education movement, a form of education coined "integrated" or "interdisciplinary" began to develop. An integrated curriculum was any one that used an interdisciplinary approach to teaching and was student-centered in that students were invited to join with their teachers in planning their learning experiences (Ravitch, 2000).

One type of integrated or interdisciplinary curriculum was environmental education, which was first officially defined in the 1960s as any educational activity that had a goal of producing citizens who had a knowledge of the environment and

\footnotetext{
${ }^{1}$ Extension Resource Educator, Cornell University, Ithaca, NY 14851-0156

${ }^{2}$ Associate Professor, Department of Agriculture, Texas State University, San Marcos, TX 78666

${ }^{3}$ Professor, The James and Marilyn Lovell Center for Environmental Geography and Hazards Research, Texas State University, San Marcos, TX 78666

${ }^{4}$ Professor, Department of Horticultural Sciences, Texas A\&M University, College Station, TX 778432133

${ }^{5}$ Corresponding author. E-mail: tcl0@txstate.edu.
}

its problems, as well as an awareness and a motivation to solve those problems (Stapp, 1969). This focus on "activity," the integrated nature of knowledge, the student taking an active role in learning, and self-motivation in environmental education paralleled much of the thought in the progressive education movement as well as in the cognitive and constructivist movements (Disenger, 1998; Fields et al., 1993; Presseisen, 1986).

One difficulty that has faced the American education system is the ability to incorporate an integrated curriculum into primary and secondary schools while satisfying national and state educational standards. Courses with nontraditional elements integrated into their curriculum have to be challenging, integrative, and exploratory (Pale et al., 2001).

An example of an integrated curriculum that has used the environment as the context for learning in K-12 schools is the National Wildlife Federation's (NWF) Schoolyard Habitat Program (SYHP; National Wildlife Federation, 2001). The SYHP grew out of an already existing NWF program called the Backyard Wildlife Habitat program that was started in 1973. This program fostered the creation of backyard wildlife habitats by private land owners (National
Wildlife Federation, 2001). Like the Backyard Wildlife Habitat, the SYHP had a certification process that the designers were awarded upon completion of a habitat (National Wildlife Federation, 2001). The requirement to become a certified site was the completion of a habitat that had the four necessary elements of a habitat: food, water, cover, and a place to raise the young (National Wildlife Federation, 2007). For the SYHP, an additional requirement was that the site be used as an educational teaching resource. Interested schools then completed an application and enclosed a small fee to the NWF to become certified (National Wildlife Federation, 2007).

The ultimate purpose of the program was to connect students, teachers, schools, community, wildlife, and the local environment (National Wildlife Federation, 2001). Students learned through hands-on activities that were intended to enhance student "comprehension and performance" (National Wildlife Federation, 2001). By creating working habitats, students were also expected to gain self-esteem and a sense of environmental stewardship (National Wildlife Federation, 2001). Teachers had the opportunity to offer a potentially powerful learning tool not only to improve environmental and ecological literacy amongst the students, but also to provide an integrated context for learning to improve students' knowledge of basic principles that they will need to know for core subject areas (National Wildlife Federation, 2001). Also, students with learning difficulties in the classroom may find certain concepts easier to retain in an outdoor hands-on venue (National Wildlife Federation, 2001). The obvious benefits for schools were to provide an on-site "field trip" and easy access to a learning tool that could potentially increase a school's academic performance (National Wildlife Federation, 2001).

The goal of the SYHP has been to create a cross-curricular learning environment while teaching about wildlife habitat and conservation (National Wildlife Federation, 2001). The purpose of the current study was to determine if the SYHP had an effect on the standardized test scores of a sampling of fourth grade students from Houston, Texas. 


\section{Materials and methods}

SAMPLE. The sample population that was used for this study was drawn from fourth grade students in the Houston Independent School District (HISD) in Texas. Schools volunteered for participation in the study. Three control group classrooms were included in the study. These classrooms had teachers that did not integrate the SYHP into their core curriculum. Control classrooms included those from Allen Elementary School (Allen), Will Rogers Elementary School (Will Rogers), and Horn Elementary School (Horn). Treatment classrooms had teachers that integrated the SYHP into their core curriculum and only included those schools that had working certified SYHP sites. Treatment classrooms included those from Elrod Elementary School (Elrod), Rice Elementary School (Rice), and West University Elementary School (W. University). Control and treatment groups coming from different schools were closely matched based upon the demographic variables of ethnicity and economic status (Table 1 ).

All treatment classrooms were certified by the NWF for completing the installation of a schoolyard habitat in their playground settings. All sites had been present for at least 1 year on the campus. The degree of participation by teachers in treatment classrooms was varied and dependent on the teacher and teaching style. However, each treatment site was monitored to control that the schoolyard habitats were maintained throughout the school year. Teachers reported using the sites each semester, but did not document frequency of use. Additionally, treatment site teachers assured researchers that they were using the SYHP sites for teaching on a regular basis.

INSTRUMENTS AND DATA COllection. Texas Assessment of Knowledge and Skills (TAKS) math and reading academic scores and demographic data were collected on sample fourth grade students. Data included information from the beginning of the Fall 2002 semester to the end of the Spring 2004 semester, so that the previous year's standardized test scores (third grade data) would be available for use in data analysis. All records were provided by the HISD research division (HISD, unpublished data).

THE NWF's SYHP CURRIculum. The curriculum and treatment used in this study was the SYHP. The SYHP was created by the NWF in 1996 with the goal of creating a cross-curricular learning environment. Schools participating in the program created and restored wildlife habitats on school grounds (National Wildlife Federation, 2001).

The SYHP curriculum was divided into two activity levels: kindergarten to grade 8 , and grade 9 to grade 12. Applications were further subdivided into segments of grade levels to align with national academic standards (National Wildlife Federation, 2001). For this study, curriculum usage by treatment group teachers was at the discretion of each individual teacher. Teachers used the curriculum as they would any other materials available for classroom curriculum development and integration.

For the purpose of helping teachers and students in Texas, the curriculum also aligned with the Texas Essential Knowledge and Skills (TEKS), the common guidelines for curriculum content and teaching. Content that students should know at each grade level for various subjects were specified by the TEKS (Texas Education Agency, 2007).

NWF provided the How-to Guide for K-12 School Communities (2001) and used 2-day workshops for teachers that explained the program, and also provided lesson plans that showed how teachers could integrate state and national standards into the program (National Wildlife Federation, 2001).

An example of how standards would be integrated for Math Standard 9: Geometry and Spatial Sense, kindergarten to grade 4, Curriculum and Evaluation Standards for School Mathematics (National Council of Teachers of Mathematics, 2007), for instance, would be, "Look for patterns in nature such as tree shapes, leaf shapes and color of leaves" (National Wildlife Federation, 2001). Also, Math Standards for Grade 4: Mathematical Connections, kindergarten to grade 4 , addresses measuring areas of schoolyards, researching migration

Table 1. Demographic profile of matched control and treatment samples and a whole sample in the study of the effects of the NWF's SYHP on the Texas Assessment of Knowledge and Skills (TAKS) math and reading scores from third to fourth grade in the study of the effect of the SYHP on the math and reading scores in fourth grade elementary school students.

\begin{tabular}{|c|c|c|c|c|c|c|c|}
\hline$\underline{S c h o o l ~(g r o u p) ~}^{z}$ & $\begin{array}{c}\text { Sample size } \\
\text { (no. students) }\end{array}$ & $\begin{array}{c}\text { Caucasian } \\
(\%)\end{array}$ & $\begin{array}{c}\text { African-American } \\
(\%)\end{array}$ & $\begin{array}{c}\text { Hispanic } \\
(\%)\end{array}$ & $\begin{array}{c}\text { Asian } \\
(\%)\end{array}$ & $\begin{array}{c}\text { Economically } \\
\text { disadvantaged } \\
(\%)\end{array}$ & $\begin{array}{c}\text { Male } \\
(\%)\end{array}$ \\
\hline Allen (control) & 30 & 0 & 36.7 & 63.3 & 0 & 90 & 66.7 \\
\hline \multicolumn{8}{|l|}{ Will Rogers } \\
\hline (control) & 89 & 11.2 & 36 & 47.2 & 5.6 & 58.4 & 39.3 \\
\hline W. Univ. (SYHP) & 140 & 82.1 & 3.6 & 7.9 & 6.4 & 6.4 & 50.7 \\
\hline Whole sample & 492 & 36.2 & 24 & 33.7 & 6.1 & 44.1 & 50.6 \\
\hline Control & 186 & 29.6 & 26.9 & 35.5 & 8.1 & 46.8 & 48.9 \\
\hline Treatment & 306 & 40.2 & 22.2 & 32.7 & 4.9 & 42.5 & 51.6 \\
\hline
\end{tabular}

${ }^{2}$ Control classrooms included those from Allen Elementary School (Allen), Will Rogers Elementary School (Will Rogers), and Horn Elementary School (Horn) in Houston, Texas. Treatment classrooms included those from Elrod Elementary School (Elrod), Rice Elementary School (Rice), and West University Elementary School (W. Univ.) in Houston, Texas. Treatment classrooms had teachers that integrated the SYHP into their core curriculum, whereas control classrooms had subjects taught using the traditional curriculum. 
routes of butterflies and birds, or calculating percentages of species within plotted areas (National Wildlife Federation, 2001).

Data analysis. TAKS test scores for the fourth grade students were obtained and considered the posttest portion for the study's control and treatment groups. TAKS test scores assess the student achievement on the TEKS, which are the state's curriculum goals (Texas Education Agency, 2007). Primary and secondary students in Texas are required to take and pass the TAKS examinations during the spring of each year to advance to the next grade. The third grade test scores of the same students were considered the pretest portion for the study's control and treatment groups.

For the purposes of this study, only the raw math and reading TAKS scores were considered. To measure academic achievement, changes in math and reading standardized test scores were compared between control and treatment groups' third and fourth grade data. Data were entered and analyzed using SPSS (v10.1 for Windows; SPSS, Chicago). A majority of the data did not meet one or more of the four assumptions needed to use parametric tests, including normality, homogeneity of variance, interval scale, and independence (Field, 2000). For this reason, nonparametric tests were used. Spearman's rho correlations were conducted to determine relationships between variables.

\section{Results and discussion}

TAKS MATH sCORES. A Spearman's rho correlation test was used to examine relationships between participation in the SYHP and TAKS math scores of students. There was a positive relationship between the control and treatment group membership and improved TAKS math scores for only one pair of schools (Horn and W. University schools). However, overall control and treatment sample comparisons showed a positive association with the use of the SYHP on TAKS math standardized test scores (Table 2). The treatment group mean score change was 2.68 compared with a control group mean score change of 1.51 .

These results support the findings of the State Education and
Environment Roundtable (SEER, 2006) study in which the understanding of mathematical concepts improved among $73 \%$ of the students' samples when an environmental integrated curriculum was used. The results also supported the findings of the Klemmer et al. (2005) study on the effects of using a school gardening program as an integrated curriculum on elementary students' math and science academic achievement.

TAKS READING scores. Spearman's rho correlations were used to determine if there was any relationship between schools that used the SYHP and TAKS reading scores of students. Again, with the exception of Horn (control) and W. University (treatment), where students in the latter showed a significantly better performance from third to fourth grade, no statistically significant correlations were found (Table 2 ).

The SYHP is designed to be aligned with the TEKS for at least seven subject areas, math and reading included. However, the basic principles behind the creation and upkeep of the SYHP are mathematical in nature and therefore are easier to

Table 2. Spearman's rho bivariate correlation between matched control and treatment schools and change in TAKS math and reading scores from third to fourth grade in the study of the effect of the SYHP on the math and reading scores in fourth grade elementary school students.

\begin{tabular}{|c|c|c|c|c|c|}
\hline School (group) ${ }^{\mathrm{z}}$ & $\begin{array}{c}\text { Sample size } \\
\text { (no. students) }\end{array}$ & $\begin{array}{l}\text { Grade } 3 \text { math } \\
\text { (mean score) }\end{array}$ & $\begin{array}{l}\text { Grade } 4 \text { math } \\
\text { (mean score) }\end{array}$ & $\begin{array}{c}\text { Grade } 3 \text { and } 4 \\
\text { (mean score change) }\end{array}$ & $\begin{array}{c}\text { Correlation } \\
\text { coefficient }\end{array}$ \\
\hline Allen (control) & 30 & 28.67 & 29.07 & 0.40 & 0.062 \\
\hline Will Rogers (control) & 88 & 30.94 & 34.30 & 3.40 & 0.068 \\
\hline Rice (SYHP) & 93 & 31.32 & 35.12 & 3.80 & \\
\hline Horn (control) & 66 & 34.70 & 34.42 & -0.39 & $0.297 * * *$ \\
\hline Control & 184 & 31.92 & 33.46 & 1.51 & $0.121 * *$ \\
\hline Treatment & 291 & 32.27 & 35.03 & 2.68 & \\
\hline School (group) & $\begin{array}{c}\text { Sample size } \\
\text { (no. students) }\end{array}$ & $\begin{array}{c}\text { Grade } 3 \text { reading } \\
(\text { mean score })\end{array}$ & $\begin{array}{c}\text { Grade } 4 \text { reading } \\
(\text { mean score })\end{array}$ & $\begin{array}{c}\text { Grade } 3 \text { and } 4 \\
\text { (mean score change) }\end{array}$ & $\begin{array}{c}\text { Correlation } \\
\text { coefficient }\end{array}$ \\
\hline Allen (control) & 30 & 26.70 & 28.30 & 1.60 & -0.020 \\
\hline W. Univ. (SYHP) & 130 & 33.19 & 36.39 & 3.14 & \\
\hline Whole sample & 458 & 29.83 & 32.78 & 2.73 & \\
\hline Control & 184 & 29.04 & 31.82 & 2.38 & 0.067 \\
\hline Treatment & 291 & 30.31 & 33.36 & 2.94 & \\
\hline
\end{tabular}

${ }^{\mathrm{z} C o n t r o l ~ c l a s s r o o m s ~ i n c l u d e d ~ t h o s e ~ f r o m ~ A l l e n ~ E l e m e n t a r y ~ S c h o o l ~(A l l e n), ~ W i l l ~ R o g e r s ~ E l e m e n t a r y ~ S c h o o l ~(W i l l ~ R o g e r s), ~ a n d ~ H o r n ~ E l e m e n t a r y ~ S c h o o l ~(H o r n) ~ i n ~ H o u s t o n, ~}$ Texas. Treatment classrooms included those from Elrod Elementary School (Elrod), Rice Elementary School (Rice), and West University Elementary School (W. Univ.) in Houston, Texas. Treatment classrooms had teachers that integrated the SYHP into their core curriculum, whereas control classrooms had subjects taught using the traditional




integrate into the curriculum when compared with reading. For instance, the measuring of plots and the numbering of species within each plot to estimate the number in the larger area, which was a specified activity in the Schoolyard Habitats: A How-to Guide for K-12 School Communities (National Wildlife Federation, 2007), presented obvious mathematical merit. Furthermore, the creation of the wildlife habitats was mathematical in nature as a general knowledge of geometry and measuring of spaces was required. Although there were reading activities included within the SYHP as well, they were more difficult to incorporate into the fieldwork of the program. Conducting reading activities outdoors within the habitat areas or having students present reports on the habitat sites are examples of the integration of reading into the curriculum (National Wildlife Federation, 2007).

DEMOGRAPHIC COMPARISONS. Spearman's rho correlations were conducted to determine if there was a difference in standardized test scores of those students that participated in the SYHP based upon the demographic variables of gender, ethnicity, and economic status. Of these three variables, only ethnicity drew any statistically significant correlations in terms of benefits to math and reading standardized test scores. The treatment school, Rice, with predominantly Hispanic and African-American students, had the highest TAKS math score improvements of all student samples. In the final analysis, non-Caucasians displayed a positive association with changes in TAKS math raw scores from third to fourth grade $(\mathrm{r}=0.121, P=$ 0.009 ). This effect may be attributable to the improvement in scores of Hispanic versus other students (respective mean change 3.47 and $1.61, r=0.176$, $P=0.001)$.

African-Americans showed a statistically significant negative relationship with the TAKS raw reading score value after participation in the SYHP curriculum $(\mathrm{r}=-0.220, P=$ $0.001)$. Their mean change from third to fourth grades was only 1.28 compared with non-African-American students whose scores changed by an average of 2.53. These findings differ from Haycock and Jerald's (2002) research on achievement scores, which revealed that African-
Americans in Texas had higher scores in reading when compared with Caucasian students from seven other states. However, Caucasian students had higher scores overall in all subject areas measured by the achievement exams (Haycock and Jerald, 2002). In contrast, Hispanic students' scores improved more than any other ethnic group (respectively, 4.05 mean change from third to fourth grade vs. 2.04 for non-Hispanic students).

There was a general improvement in TAKS reading scores among all of the schools. A large number of Hispanics within the sample schools of Allen (control), Elrod (treatment), Will Rogers (control), and Rice (treatment) may have accounted for the improvement in TAKS reading scores. The Hispanic immigrant community has been documented as having the highest limited English proficiency (Ravitch, 1995; Romanowski, 2002), therefore, it is valuable to note that this group of students improved the most in this study.

\section{Conclusions}

The NWF's SYHP is an integrated curriculum intended to familiarize students with ecological principles using an activity-based approach to learning (National Wildlife Federation, 2007). The curriculum is also aligned with various national and state academic standards, which makes the curriculum adaptable to school core curricula (National Wildlife Federation, 2007). There has been a controversy in American schools over students' abilities to keep up with the academic standards being presented to them and their ability to perform well on exams, the primary form of standardized measurement (Meier, 2002; Whitaker, 2004). There has also been a concern that using an interdisciplinary and integrated approach to curricula like that of the SYHP would detract from students' abilities to take these tests. The results from this study showed that the SYHP was associated with a positive change in the math grades of the student samples in the HISD. This finding supported other studies concerned with students' academic achievement when an interdisciplinary or integrated curriculum, particularly one with an environmental slant, was imposed (Klemmer et al., 2005; Lieberman and Hoody, 1998; Pigg et al., 2006; Stapp, 1969; Vaughn et al., 2003; Volk and McBeth, 1997).

There is also a concern in the United States that certain minority groups, specifically Hispanics and African-Americans, may be challenged more so because of other variables that tend to make up their demographic profile such as low economic status, limited English proficiency, and high mobility rates (Haycock and Jerald, 2002; Meier, 2002; Ravitch, 1995; Whitaker, 2004). Historically, the achievement gap between minority groups and Caucasians has been fairly wide, with Caucasian scores on standardized tests being consistently higher (Ravitch, 1995). According to some studies, the continuing gap may be because of not only demographic variables, but also because of the possibility that the standardized tests are racially biased toward Caucasians (Meier, 2002; Whitaker, 2004).

This study showed that although the Caucasian sample of students outperformed others on the standardized tests, the most significant improvement of overall test scores was from improved scores for Hispanic students. However, although there was a statistically significant improvement in math scores between control and treatment schools, the improvement attributable to the SYHP was only evident in the predominantly Caucasian sample school pair, indicating that students in predominantly $\mathrm{mi}$ nority schools do not gain the same level of benefit from this program.

\section{Literature cited}

Disenger, J.L. 1998. Tensions in environmental education: Yesterday, today, tomorrow, p. 34-40. In: H.R. Hungerford, W.J. Blaum, T.L. Volk, and J.M. Ramsey (eds). Essential readings in environmental education. Stipes Publishing, Champaign, IL.

Field, A. 2000. Discovering statistics using SPSS for Windows. Sage Publications, Thousand Oaks, CA.

Fields, B.C., M.K. Fields, and H. Gardner. 1993. Multiple intelligences: The theory in practice. Basic Books, New York.

Haycock, K. and C. Jerald. 2002. Closing the achievement gap. Principle 88(1):2023.

Klemmer, C.D., T.M. Waliczek, and J.M. Zajicek. 2005. Growing minds: The effect 
of a school gardening program on the science achievement of elementary students. Hort Technology 15(3):448-452.

Lieberman, G.A. and L.L. Hoody. 1998. Closing the achievement gap: Using the environment as an integrating context for learning. State education and environment roundtable. Science Wizards, Poway, CA.

Meier, D. 2002. In schools we trust: Creating communities in an era of testing and standardization. Beacon Press, Boston.

National Council of Teachers of Mathematics. 2007. Elementary school resources. 11 Nov. 2007. <http://www.nctm. org/resources/elementary.aspx $>$.

National Wildlife Federation ${ }^{\circledR}$. 2001. Schoolyard Habitats ${ }^{\circledR}$ : A how to guide for K-12 school communities. 14 Aug. 2007. <http://www.nwf.org/wildlife university/curriculum.cfm $>$.

National Wildlife Federation ${ }^{\circledR} .2007$. Schoolyard Habitats ${ }^{\circledR}$. 23 June 2007. <http://www.nwf.org/schoolyard/>.

Pale, P.E., K.F. Thompson, and M. Keyes. 2001. Students, standards, and ex- ploration: A responsive, relevant, and engaging curriculum. Middle School J. 33(1):35-40.

Pigg, A.E., T.M. Waliczek, and J.M. Zajicek. 2006. Effects of a gardening program on the academic progress of third, fourth, and fifth grade math and science students. HortTechnology 16(2):262-264.

Presseisen, B.Z. 1986. Thinking skills: Research and practice. National Education Association, Washington, DC.

Ravitch, D. 1995. National standards in American education. Brookings Institute, Washington, DC.

Ravitch, D. 2000. Left back: A century of failed school reforms. Simon \& Schuster, New York.

Romanowski, M.H. 2002. Meeting the needs of migrant students. Principle 82(2):42-47.

Stapp, W.B. 1969. The concept of environmental education, p. 22-24. In: H.R. Hungerford, W.J. Blaum, T.L. Volk, and J.M. Ramsey (eds). Essential readings in environmental education, Stipes Publishing, Champaign, IL.
State Education and Environment Roundtable. 2006. The EIC Model ${ }^{\mathrm{TM}}$. 11 Nov. 2007. <http://www.ecs.org/ clearinghouse/18/63/1863.htm>.

Texas Education Agency. 2007. Texas Essential Knowledge and Skills (TEKS). 23 June 2007. <http://www.tea.state. tx.us/teks/\#standards $>$.

Vaughn, C., H. Solorazano, J. Gack, and R. Ray. 2003. The effect of environmental education on schoolchildren, their parents, and community members: A study of intergenerational and inter-community living. J. Environ. Educ. 34(3):12-21.

Volk, T.L. and W. McBeth. 1997. Environmental literacy in the United States, p. 32-45. In: H.R. Hungerford, W.J. Blaum, T.L. Volk, and J.M. Ramsey (eds). Essential readings in environmental education, Stipes Publishing, Champaign, IL.

Whitaker, M.L. 2004. Thinking contextually about accountability. Teach. Educ. 39(4):267-280. 